\title{
Odour Removal in Leather Tannery
}

\author{
Rames C. Panda ${ }^{1,2^{*}}$, Chokalingam Lajpathi Rai ${ }^{1}$, Venkatasubramaniam Sivakumar ${ }^{1}$, Asit Baran Mandal ${ }^{1}$ \\ ${ }^{1}$ Central Leather Research Institute (CSIR), Adyar, India \\ ${ }^{2}$ Department of Chemical Engineering, Curtin University of Technology, Perth, Australia \\ Email: ${ }^{*}$ panda@clri.res.in
}

Received February 10, 2011; revised November 25, 2011; accepted December 29, 2011

\begin{abstract}
Toxic odour causes pollution to environment. Removal of odour from wet processing sections of leather tanneries is important to preserve safety and occupational health. Such odour causing gases are identified in nature and are identified mostly as ammonia, Hydrogen sulfide and Volatile organic compounds. These gases, evolving from tanning drums, were experimentally quantified and analysed. Techniques for the abatement of odorous gases are designed using chemical methods. Scrubbing towers based on absorption of gases by liquid are designed and fabricated to evaluate the performance of the system in laboratory scale. Those gases were reduced in the concentration by absorbing through the packed bed vapour phase absorption using the activated carbon as the adsorbent. Results are helpful to conclude that the absorption technique presented here to reduce these toxic emission loads, seems to be simpler and economically cheaper.
\end{abstract}

Keywords: Odour; Packed Tower; Absorbtion; Tannery; Pollution

\section{Introduction}

During the last two decades, cleaner production and pollution abatement have been developed which have made it possible to reduce the pollution load from tanneries. There are many techniques available (Riffenburg and Alison, 1941; IULTCS, 2008) [1,2] for treatment of wastewater. But less number of research are reported on pollution through air emission that give rises to bad odor and causes problem to occupational safety of the workers in Tannery. Hence the purpose of this work is to highlight sources of odor and to suggest techniques of their removal. In pre-tanning section of leather processing $\mathrm{H}_{2} \mathrm{~S}$ and $\mathrm{NH}_{3}$ and $\mathrm{VOC}$ are evolved from process and cause bad odor. From putrefying hides also bad odor comes out. Other sources are from chemical storage in tannery ( $\mathrm{HCHO}, \mathrm{CH}_{4}$ etc. gases comes out) and some organic foul gases form hides/skins during processing. In tannery, these gases either partly dissolved in process liquor, giving rise to odor or mix with air inside (tannery) and produces bad odor. In the latter case, biofilters, bioscrubbers, activated sludge scrubbers, trickling filter scrubbers, and reactive chemicals are available to suck and remove these bad odorous gases. But in the earlier case, suitable technology must be developed which is the objective of this paper. These emissions from tannery or effluent treatment plant, generally pollute the air, soil, surface water and underground water, causing serious health problems because they lie within and around residential

${ }^{*}$ Corresponding author. areas. Respiratory disorders, diarrhea, dysentery and typhoid are the most serious illnesses among the community. The limiting steps for removal of ammonia-nitrogen and hydrogen sulphide are studied in production of wet blue hides.

\section{Sources of Gases}

As mentioned earlier, the main constituents of odourous gases in tannery are VOC's (evolving during the action of enzymes causes decomposition and oxidation of the hides and skin), $\mathrm{NH}_{3}$ and $\mathrm{H}_{2} \mathrm{~S}$ (evolving during the unhairing and deliming process of tanning in the processing of leather). Out of these the $\mathrm{NH}_{3}$ and $\mathrm{H}_{2} \mathrm{~S}$ both are toxic gases which are the responsible for the odour in the tannery. The $\mathrm{NH}_{3}$ having strong pungent and $\mathrm{H}_{2} \mathrm{~S}$ having fouling smell both giving a odour in and around the tannery environment. From Zahn et al. (2001) [3] it is found that a typical tannery will have VOC- $100 \mathrm{ppm}, \mathrm{NH}_{3}-$ $40 \mathrm{ppm}$ and $\mathrm{H}_{2} \mathrm{~S}-30 \mathrm{ppm}$. Based on these loads, this work designs scrubbing systems for abatement of these toxic gases. According to ASTM standards the limits of these gases in air should be given by Table 1 .

\section{Methods of Removal}

Different methods of removal of $\mathrm{NH}_{3}$ and $\mathrm{H}_{2} \mathrm{~S}$ are available: they are generally: addition of Chemical Reagents, Passing Compressed Air, Ozone Oxidation, Biochemical method. 
Table 1. Air/water discharges, odor and exposure standards.

\begin{tabular}{ccc}
\hline & & Concentration, $\mathrm{mg} / \mathrm{m}^{3}$ \\
\cline { 2 - 3 } Item & $\mathrm{H}_{2} \mathrm{~S}$ & $\mathrm{NH}_{3}$ \\
\hline $\begin{array}{c}\text { (Air) Boundary - design ground } \\
\text { level concentration }\end{array}$ & 0.00014 & 0.6 \\
$\begin{array}{c}\text { (Air) Occupational health and safety } \\
\text { time-weighted average }\end{array}$ & 14 & 25 \\
(Air) Short term exposure limit & 21 & 35 \\
Water & between 0.025 and $0.25 \mu \mathrm{g} / \mathrm{l} \&$ sulphide $=1 \mathrm{mg} / \mathrm{lit}$ & $<0.025 \mathrm{mg} /$ lit \& kjeldahl nitrogen $<0.78 \mathrm{mg} /$ lit \\
\hline
\end{tabular}

\subsection{Removal of Odor from Process Liquor}

Different methods of removal of $\mathrm{NH}_{3}$ and $\mathrm{H}_{2} \mathrm{~S}$ are studied: They are generally:

1) Addition of Chemical Reagents;

2) Passing Compressed Air;

3) Ozone Oxidation;

4) Passing air in counter current to liquor in a packed (activated carbon) bed;

5) Biochemical and Biological methods.

Out of the above mentioned methods, the 4th one is economic and industrially feasible. Hence, trial is undertaken to study parametric effects on performance of removal of gases and design scale up.

\subsection{Passing Compressed Air \& Physical Absorption by Activated Charcoal}

This method is developed at Bench Scale laboratory of Chemical Engg Dept, CLRI, Chennai, India, after many experimental trials. As packing material, charcoal bed is used. Samples of tannery wastewater are collected from different region and from different tanning sectors to analyze sulphide and nitrogen contents in them. Methods of removal of these odor-sources by means of adding reactive-chemicals or passing compressed air or adsorption by activated charcoal, are studied and discussed. Engineering design aspects of the proposed devices (CSTR/Packed Bed) are discussed. The odor removal process is made continuous by designing and employing a flow controller by adjusting flow rate of air passing through the float in a cstr/packed bed.

\subsubsection{Experimental Setup}

For the quantitative analysis the simpler and suitable setup was made. A column taken with the passage was taken. A fresh grade of Activated Carbon is being packed into that column up to the required height of the column. A pressure gauge meter is fixed across the height of the bed to calculate the pressure crop across the total bed height. The outlet of the column, i.e., exit of the air from column is made to collect in the sample collector for the detection and analysis. A two Round Bottomed flask were made mounted with the flow controller is attached to the bottom of column. From this the gas was produced artificially and passed through the bed. The experiment was conducted with analysis of two such gases, i.e., $\mathrm{NH}_{3}$ and $\mathrm{H}_{2} \mathrm{~S}$.

\subsubsection{For Ammonia $\left(\mathrm{NH}_{3}\right)$}

The gas is artificially produced by means of heating up of the Ammonium hydroxide $\left(\mathrm{NH}_{4} \mathrm{OH}\right)$ liquid at the desired concentration. It was made pass through the bed and collected out in the $3 \%$ of $50 \mathrm{cc}$ of cold Boric acid solution. All the $\mathrm{NH}_{3}$ gases passes out are caught up in the boric acid solution and the amount of ammonia in the collection sample is determined by quantitatively.

\subsubsection{For Hydrogen Sulfide $\left(\mathrm{H}_{2} \mathrm{~S}\right)$}

The gas is produced artificially by means of heating up of the $\mathrm{Na}_{2} \mathrm{~S}$ solution of desired concentration with the Hydrochloric acid $(\mathrm{HCl})$ it produces the $\mathrm{H}_{2} \mathrm{~S}$ gas as

$$
\begin{gathered}
\mathrm{H}_{2} \mathrm{~S}+2 \mathrm{NaOH} \rightarrow \mathrm{NaHS}+\mathrm{H}_{2} \mathrm{O} \\
\mathrm{NaOH}+\mathrm{NaHS} \rightarrow \mathrm{Na}_{2} \mathrm{~S}+2 \mathrm{H}_{2} \mathrm{O}
\end{gathered}
$$

The collected $\mathrm{Na}_{2} \mathrm{~S}$ product can be determined by quantitatively. In both the cases, the experiment was carried out in the different concentration and different temperature. The corresponding pressure drop at each case was recovered for the detection of respective quantity of gas. The time of exposure or passage through the bed was kept constant for all the cases to determine consistency at a temperature for all the cases.

\subsubsection{Quantitative Analysis of the Gases}

\subsubsection{For $\mathrm{NH}_{3}$}

The collected $\mathrm{NH}_{3}$ in the boric acid solution is shaken well colded up and then it is titrated against the $\mathrm{N} / 10 \mathrm{HCl}$ with phenolphthalein as indicator. From this the amount of concentration of $\mathrm{NH}_{3}$ collected can be obtained.

\subsubsection{For $\mathrm{H}_{2} \mathrm{~S}$}

The collected $\mathrm{Na}_{2} \mathrm{~S}$ sample is titrated against the N/10 $\mathrm{ZnSO}_{4}$ solution. The titration is continued till all the $\mathrm{Na}_{2} \mathrm{~S}$ will converted to $\mathrm{ZnS}$ and $\mathrm{Na}_{2} \mathrm{SO}_{4}$ as 


$$
\mathrm{Na}_{2} \mathrm{~S}+\mathrm{ZnSO}_{4} \rightarrow \mathrm{ZnS}+\mathrm{Na}_{2} \mathrm{SO}_{4}
$$

The end point is ascertained by spotting on to the dry filter paper previously impregnated with $10 \%$ lead acetate solution and the end point is reached when no immediate brown stain is visible due to conversion of all sulfides into zinc sulfate as the above equation.

In this case, removal efficiency is observed as $83 \%$. A mathematical program was written to evaluate the process performance. The comprehensive procedure for analysis of design can be given as below:

\subsubsection{Procedure}

The steps for the process design are:

1) Set on analysers $\left(\mathrm{NH}_{3}\right.$ and $\left.\mathrm{H}_{2} \mathrm{~S}\right)$;

2) Open air inlet valve (feed is air $+\mathrm{NH}_{3}+\mathrm{H}_{2} \mathrm{~S}$ mixed) that comes out from factory;

3) Observe rotameter reading (about $20 \mathrm{psig}$ ). Air feeding rate is in $\mathrm{gmol} / \mathrm{min}$;

4) Set desired air flow, water or liquid flow rates and connect analyzers to effluent gas stream. Record rotameter readings when it comes to steady state (generally it takes 5 mins);

5) Read pressure drop across the column;

6) Calculate NTU and HTU;

7) Change the flow rates and observe the readings by repeating above steps.

\section{Mathematical Development}

The schematic of gas absorption is shown in Figure 1. The odor gas flows from bottom to top of tower while liquid flows down from top to bottom of the packed column in counter-current.

Material Balance:

Gas Feed $=\left(\right.$ Air $\left.+\mathrm{NH}_{3}+\mathrm{H}_{2} \mathrm{~S}\right)$ Liquid Feed $=$ Water

Counter current

Gas Phase:

$$
L x_{0}+V y_{F}=L x_{B}+V y_{1}
$$

With $x_{0}=0$, we get

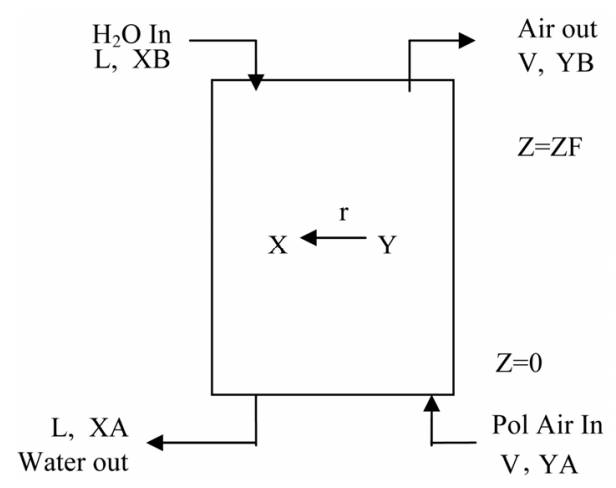

Figure 1. Schematic of gas absorption tower.

$$
x_{B}=(V / L)\left(y_{F}-y_{1}\right)
$$

Here $V=$ vapor rate in $\mathrm{g} / \mathrm{min}$ and $L=$ Liquid rate in $\mathrm{g} / \mathrm{min}$.

We consider that the air (flow rate, $V$ gmol/min) carrying the emitted gas stream enters the column of height $\mathrm{z}$ and diam $D$ where it is scrubbed with water (flow rate $=L \mathrm{gmol} / \mathrm{min}$ ) in counter current. The rate of mass transfer is given by $r=k\left[y-y^{*}(x)\right]$ Where $y$ and $x$ are gas and liquid phase concentrations in mole fraction $y^{*}(x)$ is gas phase concentration equilibrium with liquid and can be evaluated by seeing VLE data. $k$ is mass transfer coefficient. At steady state, gas phase and liquid phase transfers become equal and we get,

$$
\frac{\mathrm{d} y}{\mathrm{~d} z}=-(k / V)\left(y-y^{*}\right)
$$

Integrating from $z=0$ to $z=z_{F}$ we get

$$
\frac{k}{V} z_{F}=\int_{y_{B}}^{y_{A}} \frac{\mathrm{d} y}{y-y^{*}(x)}
$$

$=$ resistance to mass transfer. As the driving force $(y-$ $y^{*}(x)$ ) becomes less and less, the integral becomes larger and larger, thus, indicating the Number of Transfer Units (NTU) becoming more and more. It is necessary to know $x(y)$ and $y^{*}(x(y))$ to evaluate the integral.

The Operating Line:

$$
L x_{B}+V y=L x+V y_{B} \text { or } x=(V / L)\left(y-y_{B}\right)
$$

With $x_{B}=0$, the integrand reduces to

$$
\frac{1}{y-y^{*}\left((V / L)\left(y-y_{B}\right)\right)}
$$

which can be evaluated in terms of $y$ if $y^{*}(x)$ is known. Generally, from VLE relationship we know,

$$
y^{*}=K_{H} x
$$

where $K_{H}$ is called Henry's Law constant. Thus it is possible to find an analytical solution for the integrand and NTU and HTU can be calculated.

\section{Results and Discussion}

The experimental data and readings are collected and analysed that resulted information given in Table 2. The molecules of the contaminated gas attracter to and accumulate on the surface of the activated carbon. Almost of the surface area available o the internal part structure and the adsorption depend on the pore volume and pore distribution. The amount of adsorption is totally dependent on the total surface area of the activated carbon.

The performance of removal of odourous components from gas streams by the column is shown in Figure 2. At $40^{\circ} \mathrm{C}$, the tower can remove about $73 \%$ of $\mathrm{NH}_{3}$ and 
Table 2. (a) Performance analysis from experimental studies of removal of odorous gases Time $=\mathbf{2 0}$ mins: Temperature $=40^{\circ} \mathrm{C}$; (b) Performance analysis from experimental studies of removal of odorous gases Temperature $=40^{\circ} \mathrm{C}$; (c) Performance analysis from experimental studies of removal of odorous gases Temperature $=45^{\circ} \mathrm{C}$.

(a)

\begin{tabular}{ccc}
\hline Ammonia (ppm) & Pressure Drop & \% Abatement \\
\hline 800 & 10.791 & 73.2 \\
900 & 15.6 & 72.1 \\
1000 & 19.6 & 71.3 \\
Hydrogen Sulfide (ppm) & Pressure Drop & \% Abatement \\
200 & 9.8 & 70.6 \\
300 & 10.8 & 68.7 \\
400 & 12.7 & 67 \\
\hline
\end{tabular}

(b)

\begin{tabular}{ccc}
\hline Ammonia (ppm) & Pressure Drop & \% Abatement \\
\hline 800 & 25.5 & 72.40 \\
900 & 19.6 & 70.8 \\
1000 & 12.7 & 69.8 \\
Hydrogen Sulfide (ppm) & Pressure Drop & \% Abatement \\
200 & 10.8 & 69.5 \\
300 & 12.5 & 68.1 \\
400 & 14.7 & 66.7 \\
\hline
\end{tabular}

(c)

\begin{tabular}{ccc}
\hline Ammonia (ppm) & Pressure Drop & \% Abatement \\
\hline 800 & 17.6 & 72.6 \\
900 & 24.5 & 71.1 \\
1000 & 30.4 & 69.2 \\
Hydrogen Sulfide (ppm) & Pressure Drop & \% Abatement \\
200 & 12.75 & 69 \\
300 & 14.7 & 67.5 \\
400 & 17.6 & 65.3 \\
\hline
\end{tabular}

$70.5 \%$ of $\mathrm{H}_{2} \mathrm{~S}$ from the odourous gas stream having a load of 800 ppm $\mathrm{NH}_{3}$ and 200 ppm $\mathrm{H}_{2} \mathrm{~S}$ respectively. With increase in load the efficiency goes down.

The removal efficiency can be increased to $90 \%$ by recycling and by intensify driving forces. It is predicted
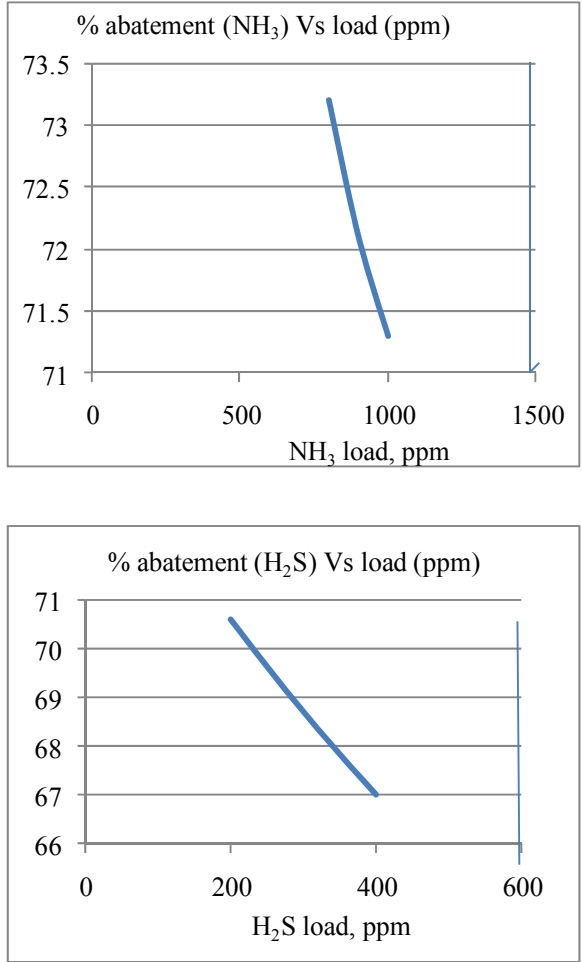

Figure 2. Performance of packed towers (removal efficiency of $\mathrm{NH}_{3}$ and $\mathrm{H}_{2} \mathrm{~S}$ ) at $40^{\circ} \mathrm{C}$.

that by increasing number of horizontal partition/segments in the packed region, residence time of gases can be increased and thereby removal efficiency can be improved.

\section{Design of Column}

The adsorption system is a simple one to design and it is made of a containment device, distribution and collection device to effect proper circulation of the gas stream through the activated carbon bed and a means for moving the gas stream through bed by using device like fan, blower or dispenser etc. The activated carbon bed can be conveniently configured into small drums or tanks depend on the size and application to the tannery. The superficial velocity $V s$ in $\mathrm{ft} / \mathrm{min}$ is given by $V s=48(f-1) / f$ where $f=1.2$ (approx) and Actual gas flow rate, $Q_{a}$ can be calculated as: $Q_{a}=\frac{19.63 Q(T+459) C_{f}}{P+14.2}$ where $Q$ is gas folw rate in mmscfd, $T$ is temperature in $F, P$ is pressure in psig and $C_{f}$ is compressibility factor, 0.95 . After finding out $Q_{a}$, the column size can be determined $I D=(A / 0.7854)^{0.5} \mathrm{ft}$. The sizing for the application depends on the surface loading rate. The standard depth of minimum $4 \mathrm{ft}$ carbon bed to maximum according to the gas flow rate and amount to be reduced. Larger flow of gas needs more height of bed in order to increase the 
surface area. The design includes the simple vessel or containment that can hold up the activated carbon.

\subsection{Reactivation and Regeneration}

Once the activated carbon is being used it has become saturated and therefore the adsorption decreases. In order to maintain the efficiency the activated carbon must be replaced with the fresh one after the every service of abatement. The carbon can be reactivated and regenerated by number of methods. The best method is washing the activated carbon in hot water and then dried off. It can be reused for the further process of adsorption.

The design calculations for the absorption tower is given as follows.

\subsection{Calculations: Packed Tower Absorption Column}

Data: Air flow rate $=7 \mathrm{cu} \mathrm{ft} / \mathrm{min}$

Temperature $=70 \mathrm{~F}$,

Pressure $=1 \mathrm{~atm}$

Water flow rate $=500 \mathrm{ml} / \mathrm{min}$

$x_{B}=0$

$\mathrm{NH}_{3}$ in air feed $=20,000 \mathrm{ppm}$

$\mathrm{H}_{2} \mathrm{~S}$ in air feed $=1000 \mathrm{ppm}$

$\mathrm{NH}_{3}$ in air exit $=250 \mathrm{ppm}$

$\mathrm{H}_{2} \mathrm{~S}$ in air exit $=5 \mathrm{ppm}$

$V=7(\mathrm{cu} \mathrm{ft} / \mathrm{min})(28.32 \mathrm{~L} / \mathrm{ft} 3)(\mathrm{gmol} / 22.4 \mathrm{~L})(492 / 530)$

$=8.125 \mathrm{gmol} / \mathrm{min}$

$L=500(\mathrm{ml} / \mathrm{min})(1 \mathrm{~g} / \mathrm{ml})(1 \mathrm{gmol} / 18 \mathrm{gm})$

$=27.8 \mathrm{gmol} / \mathrm{min}$

$y_{A 1}=(20,000 / 17) /(1,000,000 / 29)=0.034$

$y_{A 2}=(1000 / 34) /(1,000,000 / 29)=0.0034$

$y_{B 1}=(250 / 17) /(1,000,000 / 29)=0.00043$

$y_{B 2}=(05 / 34) /(1,000,000 / 29)=0.0000172$

Equilibrium data: From Perry Handbook,

$\mathrm{p}_{\mathrm{NH}_{3}}$ over 0.05 mole fraction aq $\mathrm{NH}_{3}=0.047$

psia $=0.047 / 14.7=0.0319$ mole fraction $\mathrm{NH}_{3}$ and 98.15/101.325 = 0.968 mole frac $\mathrm{H}_{2} \mathrm{~S}$

For $\mathrm{NH}_{3}: \mathrm{K}_{\mathrm{H}}=y / x=0.0319 / 0.050=0.638$

For $\mathrm{H}_{2} \mathrm{~S}: \mathrm{K}_{\mathrm{H}}=y / x=0.968 / 0.050=0.099$

Operating Line:

$$
\begin{aligned}
& x=(V / L) y-y_{B}=0.296 y-0.00043 \\
& \text { and } \begin{aligned}
y-y^{*} & =y-K_{H} x \\
& =y-0.638(0.296 y-0.00043) \\
& =0.818 y+0.000274
\end{aligned}
\end{aligned}
$$

$$
N T U=\int_{0.00042}^{0.034} \frac{\mathrm{d} y}{y-y^{*}(x)}=4.70223
$$

It also looks into the possibility of the usage of controllers for effective treatment process. With variation of process recipe and quality of hides, sulphide content of process liquor may vary at the exit. Hence to balance the load changes, an air flow controller is necessary. Accordingly, air flow rate is controlled/adjusted to maintain the emission standards.

\section{Conclusion}

Chemical engineering methods are used to reduce odourous gas loading from leather industry. From the above study it was clear that the adsorption of the toxic gases such as ammonia and $\mathrm{H}_{2} \mathrm{~S}$ are quantitatively reduced by passing through vapour phase adsorption. Here it was concluded that the application of the vapour phase adsorber with activated carbon would become the simple and economically cheaper in all the aspects from the installation to the running. And also it was clear that this method would give the better results in the reduction of odour in the effluent. This could be a better method if implemented in the end process of the effluent treatment to reduce the concentration of the contaminants and thus helpful for reducing pollution and global warming.

\section{Acknowledgments}

The authors are willing to acknowledge the help from network project (NWP-044) to carry-out the experiments.

\section{REFERENCES}

[1] IULTCS, "IUE-8: Recommendations for Odor Control in Tanneries," 2008. http://www.iultcs.org/pdf/IUE8_2008.pdf

[2] H. B. Riffenburg and W. W. Alison, "Treatment of Tannery Wastes with Flue Gas and Lime," Industrial \& Engineering Chemistry Research, Vol. 33, No. 6, 1941, pp. 801-803. doi:10.1021/ie50378a026

[3] J. A. Zahn, et al., "Correlation of Human Olfactory Responses to Airborne Concentrations of Malodorous Volatile Organic Compounds Emitted from Swine Effluent," Journal of Environmental Quality, Vol. 30, No. 2, 2000, pp. 624-634. doi:10.2134/jeq2001.302624x 